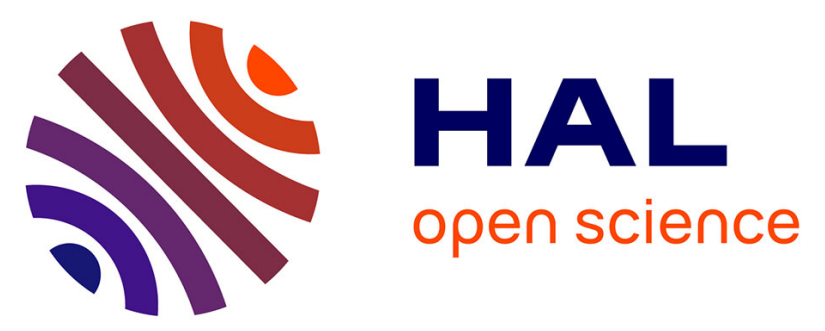

\title{
Localization and characterization of evolutionarily conserved chromogranin A-derived peptides in the rat and human pituitary and adrenal glands
}

Maïté Montero-Hadjadje, Hubert Vaudry, Valérie Turquier, Jérôme Leprince, Jean-Luc Do Rego, Laurent Yon, Nicole Gallo-Payet, Pierre-François Plouin, Youssef Anouar

\section{To cite this version:}

Maïté Montero-Hadjadje, Hubert Vaudry, Valérie Turquier, Jérôme Leprince, Jean-Luc Do Rego, et al.. Localization and characterization of evolutionarily conserved chromogranin A-derived peptides in the rat and human pituitary and adrenal glands. Cell and Tissue Research, 2002, 310 (2), pp.223 236. 10.1007/s00441-002-0625-9 . hal-01706424

\section{HAL Id: hal-01706424}

\section{https://hal-normandie-univ.archives-ouvertes.fr/hal-01706424}

Submitted on 19 Jul 2018

HAL is a multi-disciplinary open access archive for the deposit and dissemination of scientific research documents, whether they are published or not. The documents may come from teaching and research institutions in France or abroad, or from public or private research centers.
L'archive ouverte pluridisciplinaire HAL, est destinée au dépôt et à la diffusion de documents scientifiques de niveau recherche, publiés ou non, émanant des établissements d'enseignement et de recherche français ou étrangers, des laboratoires publics ou privés. 


\begin{abstract}
Chromogranin A $(\mathrm{CgA})$ is a neuroendocrine protein that undergoes proteolytic cleavage in secretory granules. The aim of the present study was to characterize the peptides WE14 and EL35 that are derived from evolutionarily conserved regions of $\mathrm{CgA}$ in rat and human endocrine tissues. In the rat pituitary, HPLC analysis revealed that WE14 is present as a single immunoreactive peak, whereas EL35 elutes in two molecular forms. Authentic WE14 is also produced in both rat and human adrenal glands, while EL35 displays a variable elution profile depending on the tissue extract, indicating the existence of different forms of EL35 in these tissues. Immunohistochemical labeling of the rat pituitary showed that WE14 and EL35 occur in gonadotropes and melanotropes, but not in corticotropes. A strong immunoreaction for both peptides was also observed in rat adrenochromaffin cells. In the human adrenal gland, the WE14 and EL35 antisera revealed intense labeling of
\end{abstract}

This work was supported by grants from the Institut National de la Santé et de la Recherche Médicale (INSERM U413), a FranceQuebec exchange programme, a Programme Hospitalier de Recherche Clinique (grant AOM-95-201 for the COMETE Network), and the Conseil Régional de Haute-Normandie

M. Montero-Hadjadje $\cdot$ H. Vaudry $(\bullet) \cdot$ V. Turquier $\cdot$ J. Leprince J.-L. Do Rego · L. Yon · Y. Anouar

European Institute for Peptide Research (IFRMP 23),

Laboratory of Cellular and Molecular Neuroendocrinology,

INSERM U413, UA CNRS, University of Rouen,

76821 Mont-Saint-Aignan, France

e-mail: hubert.vaudry@univ-rouen.fr

Fax: +33-235-146946

N. Gallo-Payet

Service of Endocrinology, Department of Medicine,

Faculty of Medicine, University of Sherbrooke, Sherbrooke,

Quebec, Canada

P.-F. Plouin

Service d'Hypertension Artérielle,

Hôpital Européen Georges Pompidou, 75908 Paris, France adrenomedullary cells in adult and nests of chromaffin progenitor cells in fetal adrenal. Finally, WE14 and EL35 immunoreactivity was detected in pheochromocytoma tissue where WE14 occurred as a single immunoreactive form, while EL35 displayed different forms. The observations that WE14 and EL35: (1) have been preserved during vertebrate evolution, (2) are processed in a cell-specific manner, and (3) occur during ontogenesis of the adrenal gland strongly suggest that these peptides play a role in endocrine tissues. In addition, the existence of differentially processed $\mathrm{CgA}$-derived peptides in normal and tumorous tissues may provide new tools for the diagnosis and prognosis of neuroendocrine tumors.

Keywords Chromogranin A · WE14 - EL35 - Peptides · Pituitary · Adrenal $\cdot$ Rat (Wistar) $\cdot$ Human

\section{Introduction}

Chromogranin $\mathrm{A}(\mathrm{CgA})$ is a member of the granin family of acidic secretory polypeptides that are present in large dense-core vesicles of neurons and neuroendocrine and endocrine cells. Chromogranin A is widely used as a marker for the identification of neuroendocrine cells and for the diagnosis of neuroendocrine tumors (Deftos 1991; Rosa and Gerdes 1994; Helle 2000). It has recently been shown that $\mathrm{CgA}$ plays a fundamental role in the biogenesis of secretory granules since depletion of this protein provoked a marked reduction of the number of these dense-core vesicles in neuroendocrine cells (Kim et al. 2001). The cloning of mammalian granins, including $\mathrm{CgA}$, chromogranin $\mathrm{B}(\mathrm{CgB})$, and secretogranin II (SgII), uncovered the existence of several potential cleavage sites for prohormone convertases (Iacangelo et al. 1986; Benedum et al. 1987; Gerdes et al. 1989), suggesting that granins represent precursor proteins that may give rise to biologically active peptides. In fact, sev- 
Fig. 1 A Schematic representation of the structure of human, rat, and frog chromogranin $\mathrm{A}$ $(\mathrm{CgA})$ showing the location of the conserved regions (shaded zones) and potential dibasic cleavage sites. These regions give rise to vasostatin I and II (VS I/VS II), WE14, and EL35. The numbers indicate the positions of the $\mathrm{N}$ - and C-terminal residues of the peptides delimited by dibasic motifs. B Alignment of the sequences of WE14 and EL35 in different species. The percentages of amino acid identity are indicated. Amino acid substitutions are highlighted by bold letters

A

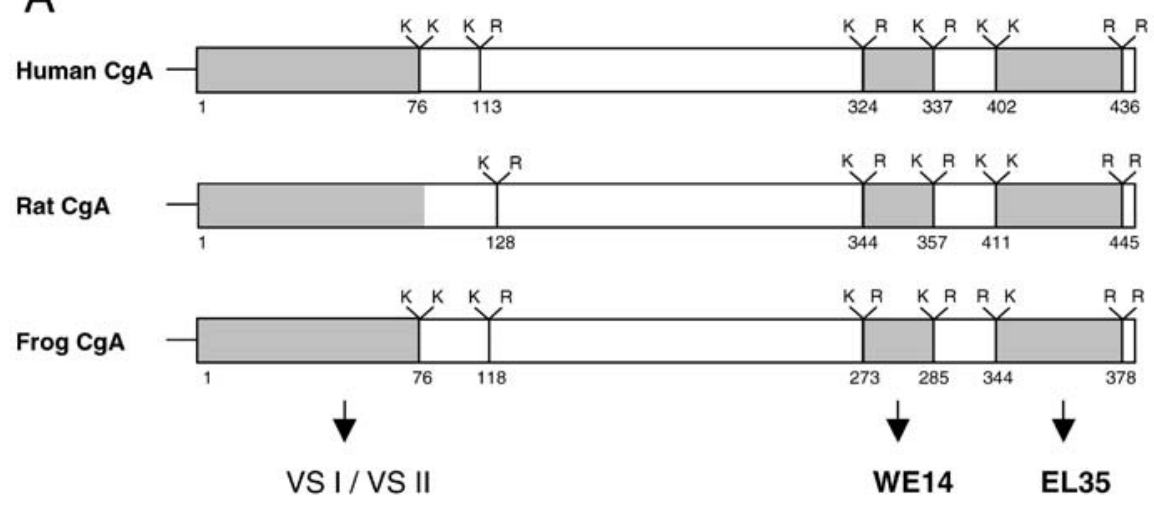

B

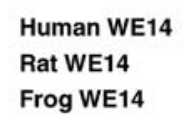

Human EL35

Rat EL35

Frog EL35

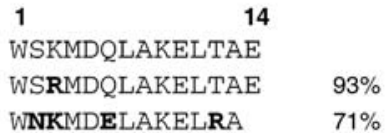

1

EEEGSANRRPEDOELESL SAIEAELEKVAHOLOAL EEEGSANRRAEDQELESLSAIEAELEKVAHQLQAL EEEGSANRKTEDQELESLAAIEAELENVAHKLHDL
$97 \%$

$80 \%$ eral $\mathrm{CgA}$-derived peptides endowed with biological activities have been described, including pancreastatin, a polypeptide isolated from the pancreas which inhibits glucose-stimulated insulin secretion (Tatemoto et al. 1986; Iacangelo et al. 1988) and two N-terminal processing products of $\mathrm{CgA}$, named vasostatin I and II (VS I and VS II) in consideration of their vasoconstriction inhibitory effect on human blood vessels, which have been identified in the adrenal medulla (Aardal et al. 1993; Stridsberg et al. 2000). Recently, it has been shown that VS I possesses potent antibacterial and antifungal activities (Lugardon et al. 2000). Chromogranin A is also the precursor protein of catestatin, a 21-amino acid peptide which inhibits catecholamine release from adrenochromaffin cells (Mahata et al. 2000).

Characterization of the cDNAs encoding $\mathrm{CgA}, \mathrm{CgB}$, and $\mathrm{SgII}$ in the frog Rana ridibunda (Anouar et al. 1996; Turquier et al. 1999, 2000; Ait-Ali et al. 2002), the toad Xenopus laevis (Holthuis and Martens 1996), and the goldfish Carassius auratus (Blazquez et al. 1998) has revealed the existence of sequences that have been selectively conserved in phylogenetically distant species. For example, the sequence of the SgII-derived peptide secretoneurin $(\mathrm{SN})$ has been strongly preserved during evolution (Vaudry and Conlon 1991; Leitner et al. 1998) and SN appears to be involved in endocrine-immune system interactions (Wiedermann 2000). The conserved sequences within CgA encompassed the N-terminal bioactive peptide VS I, a 14-amino acid peptide named WE14 which corresponds to a peptide previously identified in pheochromocytoma (Conlon et al. 1992) and ileal (Curry et al. 1992) tumors, and a putative C-terminal 35-amino acid peptide, that we named EL35 (Fig. 1A), which had never been described before. These peptides show $70-97 \%$ amino acid sequence identity between the different species (Fig. 1B) and may represent ancient, evolutionarily conserved, bioactive domains of $\mathrm{CgA}$. In the present study, we sought to characterize WE14 and EL35 in rat and human endocrine tissues in order to gain insight into the possible function of these peptides.

\section{Materials and methods}

Animals and tissue samples

Three-month-old male Wistar rats, weighing 250-300 g, were maintained under controlled conditions of temperature $\left(22^{\circ} \mathrm{C}\right)$ and an established photoperiod (lights on, 0700-1900 hours daily).

Rats had free access to laboratory chow (UAR, Epinay-sur-Orge, France) and water. All manipulations were performed according to the recommendations of the French ethics committee and under the supervision of authorized investigators. The animals were killed by decapitation between 0830 and 0930 hours, and the adrenal glands and pituitaries were quickly removed. Fetal human adrenal glands were collected from 20-week-old fetuses, after therapeutic abortion. Adult adrenal glands were obtained from patients undergoing expanded nephrectomy for kidney cancer. After surgery, the glands were frozen at $-80^{\circ} \mathrm{C}$. The protocols of collection of the tissues were approved by the human subject ethics committee of our institutions.

Peptide synthesis

Human CgA fragments WE14 and EL35 (Fig. 1B), and their $\mathrm{N}$-terminally tyrosylated variants, $\left[\mathrm{Tyr}^{0}\right] \mathrm{WE} 14$ and $\left[\mathrm{Tyr}^{0}\right] \mathrm{EL} 35$, were synthesized by the solid-phase methodology using a 433A Applied Biosystems peptide synthesizer and standard manufacturer's procedures as previously described (Leprince et al. 1998). Synthetic peptides were purified by reversed-phase high-perfor- 
mance liquid chromatography (RP-HPLC) on a semipreparative $1 \times 25-\mathrm{cm}$ Vydac $\mathrm{C}_{18}$ column (Touzart et Matignon, Courtaboeuf, France) using a linear gradient (10-50\% over $50 \mathrm{~min}$ ) of acetonitrile/trifluoroacetic acid (TFA) (99.9:0.1 v/v) at a flow rate of $5 \mathrm{ml} / \mathrm{min}$. Analytical RP-HPLC was performed on a Vydac $\mathrm{C}_{18}$ column $(0.45 \times 25 \mathrm{~cm})$ using a linear gradient $(10-40 \%$ over $30 \mathrm{~min}$ ) of acetonitrile/TFA at a flow rate of $1 \mathrm{ml} / \mathrm{min}$. The purified peptides were characterized by fast atom bombardment mass spectrometry on a conventional EB geometry mass spectrometer Jeol model AX-500 equipped with a DEC data system (JeolEurope SA, Croissy-sur-Seine, France).

\section{Antibodies}

Synthetic WE14 and EL35 (human sequences) were covalently linked to bovine thyroglobulin using glutaraldehyde as a coupling agent. Briefly, $6 \mathrm{mg}$ of each peptide was dissolved in $4 \mathrm{ml} 50 \mathrm{mM}$

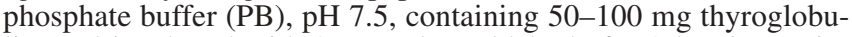
lin, and incubated with $8 \mathrm{mM}$ glutaraldehyde for $2 \mathrm{~h}$. The conjugates were dialyzed against PB for $24 \mathrm{~h}$ and kept frozen at $-20^{\circ} \mathrm{C}$. New Zealand rabbits were injected intradermally, at 1-month intervals, with the conjugates emulsified with Freund's adjuvant.

The mouse monoclonal antibody against LH $\beta$ subunit (code number 518 B7) was a generous gift from Dr. J.F. Roser (Matteri et al. 1987). The ACTH antibody raised in sheep against $\mathrm{ACTH}_{1-24}$ (code number 105-10) was a generous gift from Dr. J. Cote (Jégou et al. 1983). The mouse monoclonal antibody against tyrosine hydroxylase $(\mathrm{TH})$ was purchased from Chemicon International (Temecula, Calif., USA). The rabbit antiserum against human $\mathrm{CgA}$ was from Dako (Glostrup, Denmark). Fluorescein isothiocyanate (FITC)-conjugated goat anti-mouse $\gamma$-globulins (GAM/FITC), FITC-conjugated donkey anti-sheep $\gamma$-globulins (DAS/FITC), and Texas red-conjugated donkey anti-rabbit $\gamma$-globulins (DAR/TXR) were from Amersham International (Aylesbury, UK). Alexa-488conjugated goat anti-rabbit $\gamma$-globulins (GAR/Alexa-488) were from Molecular Probes (Leiden, The Netherlands).

\section{SDS-PAGE and Western blot analysis}

Whole rat adrenals and pituitaries were homogenized in $10 \mathrm{mM}$ TRIS-HCl, pH 7.4, containing $0.05 \%$ Triton X-100 and $1 \mathrm{mM}$ phenylmethylsulfonyl fluoride. After centrifugation $(12,000 \mathrm{~g}$ for $10 \mathrm{~min}$ at $4^{\circ} \mathrm{C}$ ), the soluble proteins were precipitated by trichloroacetic acid (10\% final concentration) and electrophoresed on a $10 \%$ polyacrylamide gel in denaturing conditions (SDS-PAGE). Proteins were electroblotted onto a nitrocellulose sheet and revealed with antibodies against WE14 and EL35, using a chemiluminescence detection kit (Amersham).

\section{Immunohistochemical procedure}

Rat adrenal and pituitary glands were dipped overnight in Stefanini's fixative (4\% paraformaldehyde, $0.2 \%$ picric acid in $\mathrm{PB}, \mathrm{pH}$ 7.4), rinsed with $\mathrm{PB}$, and frozen at $-80^{\circ} \mathrm{C}$ in Tissue-Tek (Leica, Nussloch, Germany). Frozen glands were sliced into $10-\mu \mathrm{m}$ sections in a cryomicrotome (Frigocut; Reichert-Jung, Nussloch, Germany). Frozen human adrenal glands were sliced into $10-\mu \mathrm{m}$ sections, collected on gelatin-coated slides, and dipped into Stefanini's fixative at $4^{\circ} \mathrm{C}$ for $30 \mathrm{~min}$. After several rinses in $\mathrm{PB}$, sections were processed for indirect immunofluorescence microscopy. Tissue slices were incubated overnight at $4^{\circ} \mathrm{C}$ with one of the primary antibodies (or simultaneously with two primary antibodies for double-labeling experiments), i.e., the WE14 antiserum (code number 333-1506) diluted 1:500, the EL35 antiserum (code number 555-1506) diluted 1:200, the CgA antiserum diluted 1:500, the monoclonal TH antibody diluted 1:200, the monoclonal LH $\beta$ antibody diluted 1:300, or the ACTH antiserum diluted $1: 1,000$ in PB containing $0.3 \%$ Triton $\mathrm{X}-100$ and $1 \%$ bovine serum albumin (BSA; Roche Diagnostics, Mannheim, Germany). Tissue sections were rinsed in $\mathrm{PB}$ for $30 \mathrm{~min}$ and incubated at room temperature for $90 \mathrm{~min}$ with the appropriate secondary antibody, i.e., GAR/Alexa-488 diluted 1:100, DAS/FITC diluted 1:100, GAM/FITC diluted 1:100, or DAR/TXR diluted 1:50. Finally, slices were rinsed, mounted in PB/glycerol (1:1), coverslipped, and examined using a confocal laser scanning microscope (Leica, Heidelberg, Germany) equipped with a diaplan optical system and an argon/krypton ion laser (excitation wavelengths: $488 / 568 / 647 \mathrm{~nm}$ ). To verify the specificity of the immunoreaction, the following controls were performed: (1) substitution of the primary antibodies with $\mathrm{PB},(2)$ incubation with non-immune rabbit serum instead of the primary antisera, and (3) preincubation of the WE14 or EL35 antisera (diluted 1:500 and 1:200, respectively) with the corresponding synthetic peptides $\left(10^{-6} \mathrm{M}\right)$.

\section{Tissue extraction}

Frozen tissues were immersed for $10 \mathrm{~min}$ in a cooled solution of $75 \%$ ethanol- $18 \% \mathrm{HCl}(10 \mathrm{~N})$. The tissue samples were sonicated and centrifuged $\left(10,000 \mathrm{~g}\right.$ for $30 \mathrm{~min}$ at $\left.4^{\circ} \mathrm{C}\right)$. The supernatants were collected and dried by vacuum centrifugation (Speed-Vac Concentrator; Savant AES 2000, Hicksville, N.Y., USA). The samples were reconstituted in $0.1 \%$ TFA in water and loaded onto three Sep-Pak $\mathrm{C}_{18}$ cartridges. The bound material was eluted with a solution of acetonitrile-water-TFA (56:43.9:0.1 v/v/v). The solvent was evaporated by vacuum centrifugation and the samples were kept dry until direct RIA or chromatographic analysis.

\section{High-performance liquid chromatography analysis}

Dried samples were reconstituted in $1 \mathrm{ml} 0.1 \%$ TFA and centrifuged $\left(10,000 \mathrm{~g}\right.$ for $10 \mathrm{~min}$ at $\left.4^{\circ} \mathrm{C}\right)$. The supernatants were injected onto a $0.45 \times 25-\mathrm{cm}$ Vydac $\mathrm{C}_{18}$ column equilibrated with a solution of acetonitrile-water-TFA (9.9:90:0.1 v/v/v) at a flow rate of $1 \mathrm{ml} / \mathrm{min}$. The concentration of acetonitrile in the eluting solvent was raised to $56 \%$ over $60 \mathrm{~min}$ using a linear gradient. Synthetic human WE14 and EL35 (1 $\mu \mathrm{g}$ each) were chromatographed in the same conditions. One-milliliter fractions were collected, evaporated, and kept dry until RIA.

\section{Radioimmunoassays}

The concentrations of WE14- and EL35-like material in the human and rat tissues were measured by RIA. Synthetic [Tyr $\left.{ }^{0}\right]$ WE14 and $\left[\mathrm{Tyr}^{0}\right]$ EL35 were iodinated by the chloramine-T method and separated from free iodine on Sep-Pak $\mathrm{C}_{18}$ cartridges using a step gradient of acetonitrile (20-50\% and 30-60\%, respectively) in $0.1 \%$ TFA. The radioiodinated $\left[\mathrm{Tyr}^{0}{ }^{0}\right.$ WE14 and $\left[\mathrm{Tyr}^{0}\right] \mathrm{EL} 35$ eluted at $26 \%$ and $42 \%$ acetonitrile, respectively. The RIAs were performed in $20 \mathrm{mM}$ veronal buffer, $\mathrm{pH} 9.1$, containing 3\% BSA. The WE14 and EL35 antisera, used at a final dilution of 1:120,000 and $1: 48,000$, respectively, were incubated with $7,000 \mathrm{cpm}$ of tracer/ tube in the presence of the synthetic peptide, tissue extracts, or HPLC fractions. After a 2-day incubation at $4{ }^{\circ} \mathrm{C}$, the antibodybound fraction was immunoprecipitated by the addition of $200 \mu \mathrm{l}$ goat anti-rabbit $\gamma$-globulins (1:30), $200 \mu$ normal rabbit serum $(1: 150)$, and $500 \mu \mathrm{l}$ of $5 \%$ polyethylene glycol 8,000. After a $2-\mathrm{h}$ incubation at room temperature, the mixture was centrifuged $\left(5,000 \mathrm{~g}\right.$ for $30 \mathrm{~min}$ at $\left.4^{\circ} \mathrm{C}\right)$ and the pellet containing the bound fraction was counted on a gamma-counter (LKB Wallack, Rockville, Md., USA).

\section{Results}

\section{Characterization of the WE14 and EL35 antibodies}

Western blot analysis of rat adrenal and pituitary extracts was performed to determine the respective cross-reactiv- 
Fig. 2A-D Characterization of the antibodies directed against WE14 and EL35. A, B Western blot analysis of rat pituitary (lane 1) and adrenal gland (lane 2) extracts using WE14 (A) and EL35 (B) antibodies. Molecular mass markers in kilodaltons are indicated. C, D Radioimmunoassay of WE14 and EL35. Antibodybound ${ }^{125}$ I-labeled [Tyr ${ }^{0}$ ]WE14 or $\left[\mathrm{Tyr}^{0}\right]$ EL35 was displaced by increasing concentrations of synthetic human WE14 (C) or EL35 (D). EM66 (X), SN (solid triangles), and WE14 (solid diamonds) or EL35 (solid squares) were tested for crossreactivity
A

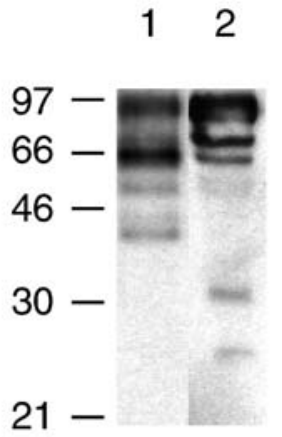

B

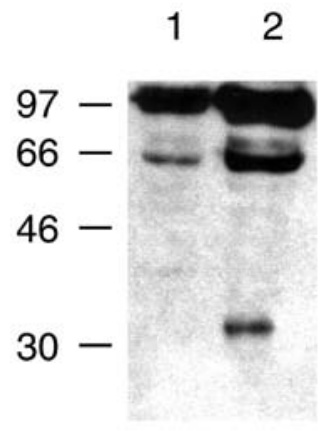

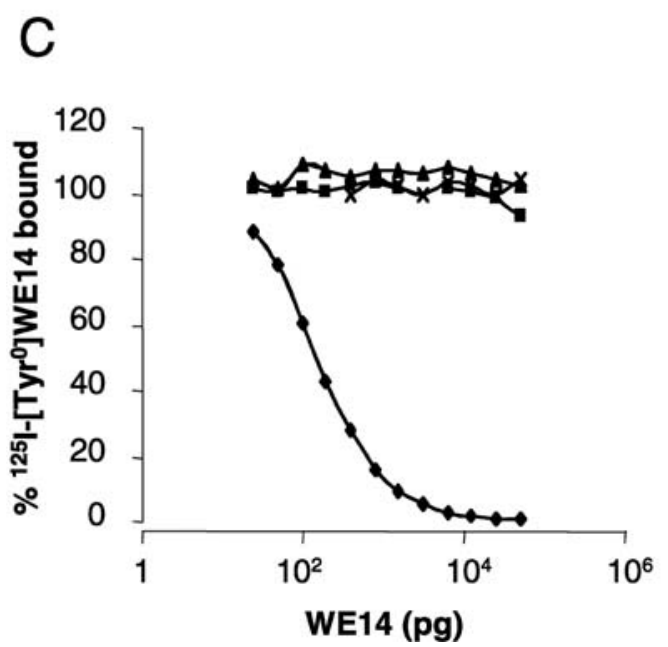

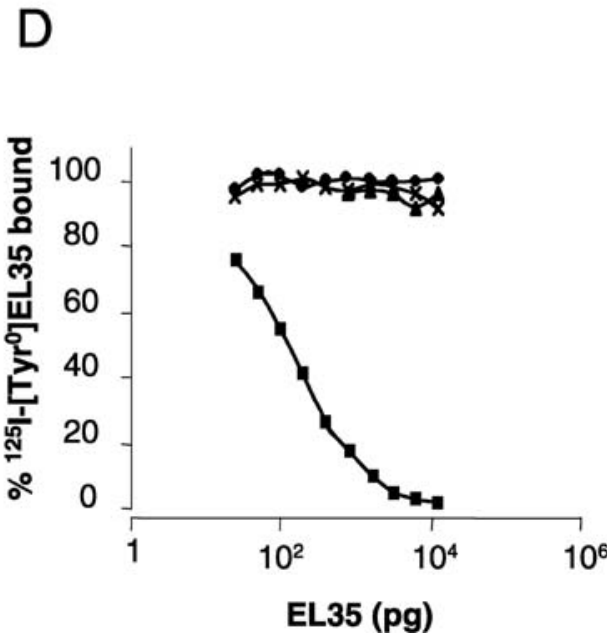

ity of the WE14 and EL35 antibodies with CgA and its intermediate processing products (Fig. 2A, B). The WE14 antiserum revealed, in addition to rat $\mathrm{CgA}$ which migrates to an apparent molecular mass of $97 \mathrm{kDa}$, several bands of lower molecular mass ranging from about 80 to $40 \mathrm{kDa}$ in the pituitary (Fig. 2A lane 1 ) and from 80 to $25 \mathrm{kDa}$ in the adrenal gland (Fig. 2A lane 2). The EL35 antiserum also stained the precursor protein and several intermediate processing products with a lower molecular mass ranging from about 80 to $40 \mathrm{kDa}$ in the pituitary (Fig. 2B lane 1) and from 80 to $30 \mathrm{kDa}$ in the adrenal gland (Fig. 2B lane 2). Worthy of note, the WE14 and EL35 antibodies revealed different intermediate products in the pituitary and adrenal extracts (Fig. 2A, B compare lanes 1 and 2), indicating that distinct processing mechanisms of $\mathrm{CgA}$ occur in these two endocrine tissues. In addition, the WE14 antibody labeled more immunoreactive bands than the EL35 antibody (Fig. 2 compare A and B), suggesting a more efficient cleavage of EL35 than WE14.

The specificity of the WE14 and EL35 antibodies was also assessed by RIA. Synthetic WE14 and EL35 displaced, respectively, antibody-bound ${ }^{125} \mathrm{I}-\left[\mathrm{Tyr}^{0}\right] \mathrm{WE} 14$ and ${ }^{125} \mathrm{I}-\left[\mathrm{Tyr}^{0}\right] \mathrm{EL} 35$ in a dose-dependent manner (Fig. 2C, D). The WE14 antibody did not exhibit any cross-reac- tivity with EL35 or SgII-derived peptides such as SN or EM66 (Fig. 2C). Similarly, the EL35 antibody did not cross-react with WE14, SN, or EM66 (Fig. 2D).

WE14 and EL35 immunoreactivity in the rat pituitary and adrenal

The WE14 and EL35 antibodies strongly labeled scattered cells in the anterior lobe of the rat pituitary and moderately stained most melanotropes in the intermediate lobe (Fig. 3A, B). Preabsorption of the primary antibodies with $10^{-6} \mathrm{M}$ WE14 (Fig. 3C) and $10^{-6} \mathrm{M}$ EL35 (Fig. 3D) totally abolished the labeling, thus confirming the specificity of the immunoreactions. No staining was observed when the WE14 or EL35 antisera were substituted with non-immune rabbit serum or PB (data not shown). Co-incubation of pituitary sections with the anti-WE14 and anti-LH $\beta$ antibodies revealed that most gonadotropes contain WE14-like immunoreactivity (li; Fig. 4A-C). Likewise, co-incubation of pituitary slices with the anti-EL35 and anti-LH $\beta$ antibodies showed the presence of EL35-li in gonadotropes (Fig. 4D-F). However, some WE14- or EL35-immunoreactive cells did not exhibit any LH $\beta$-li (red cells in Fig. 4C, F), indicating 
Fig. 3A-D Immunofluorescence labeling of WE14 and EL35 in the rat pituitary. Antisera against WE14 (A) and EL35 (B) produced intense labeling of scattered cells in the anterior lobe $(A L)$ and moderate labeling of melanotropes in the intermediate lobe $(I L)$. Consecutive sections were incubated with the WE14 and EL35 antisera preabsorbed, respectively, with $10^{-6} \mathrm{M} \mathrm{WE} 14$ (C) or $10^{-6}$ M EL35 (D). Bars $100 \mu \mathrm{m}$
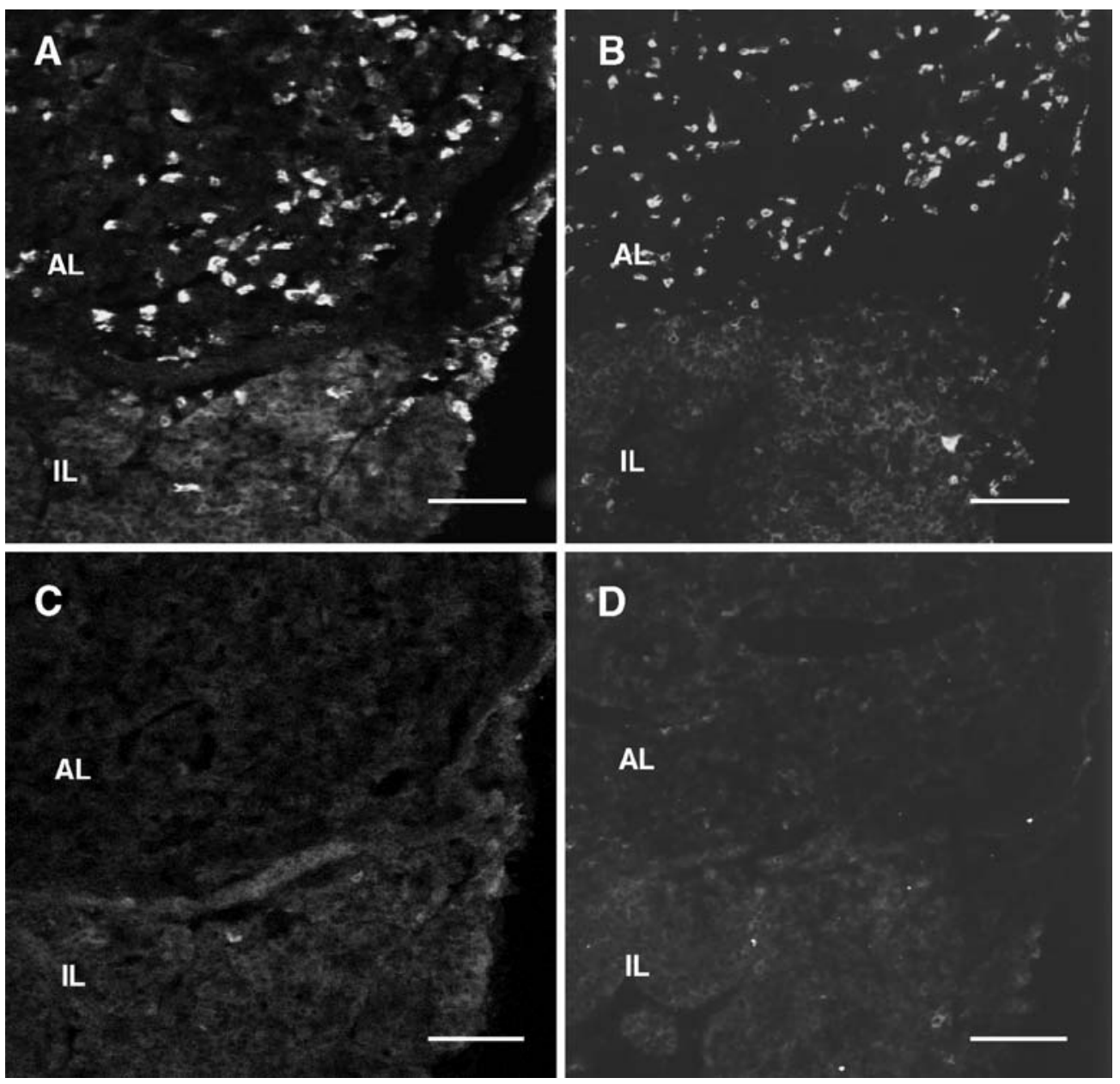

that $\mathrm{CgA}$-derived peptides may occur in cells other than gonadotropes. Reciprocally, a few gonadotropes did not stain for CgA-derived peptides (green cells in Fig. 4F), suggesting that these peptides are not present in all gonadotropes of the male rat pituitary. In contrast to gonadotropes, corticotropes that were immunostained with the ACTH antibodies, were totally devoid of WE14-li (Fig. 5A-C) and EL35-li (Fig. 5D-F).

In the rat adrenal gland, all cells that were immunolabeled with the WE14 (Fig. 6A) and EL35 (Fig. 6D) antisera were stained with the TH antibodies (Fig. 6B, E) as shown by the composite images (Fig. 6C, F), indicating that the $\mathrm{CgA}$-derived peptides are present in chromaffin cells. Cortical cells were totally devoid of labeling (Fig. 6A-F).

WE14 and EL35 immunoreactivity in the human adrenal gland

Labeling with the antisera against WE14 and EL35 revealed the presence of clusters of positive cells in the fetal human adrenal gland (Fig. 7A, B). Incubation of consecutive sections with an antiserum against $\mathrm{CgA}$, which is a selective and commonly used marker of chromaffin cells, produced immunostaining of similar groups of cells (Fig. 7C), indicating that $\mathrm{CgA}$ and $\mathrm{CgA}$-derived peptides are produced in human chromaffin progenitor cells. Immunolabeling was also observed in the central region of the adult adrenal gland using antisera against WE14 (Fig. 7D) and EL35 (Fig. 7E). Staining of a consecutive section with the $\mathrm{TH}$ antiserum showed that WE14 and EL35 were exclusively present in chromaffin cells, whereas adrenocortical cells were totally devoid of labeling (Fig. 7F).

Because $\mathrm{CgA}$ is an established marker of pheochromocytoma, we sought to characterize WE14 and EL35 in these human tumors. Immunohistochemical labeling revealed the occurrence of clusters of WE14- (Fig. 8A) and EL35-immunoreactive (Fig. 8B) cells. The same groups of cells were also labeled by the antiserum directed against $\mathrm{CgA}$ (Fig. 8C).

\section{WE14 and EL35 concentrations in tissue extracts}

Serial dilutions of extracts from the rat adrenal and pituitary glands generated displacement curves that were parallel to that obtained with synthetic human WE14 (Fig. 9A). In contrast, the displacement curves obtained 

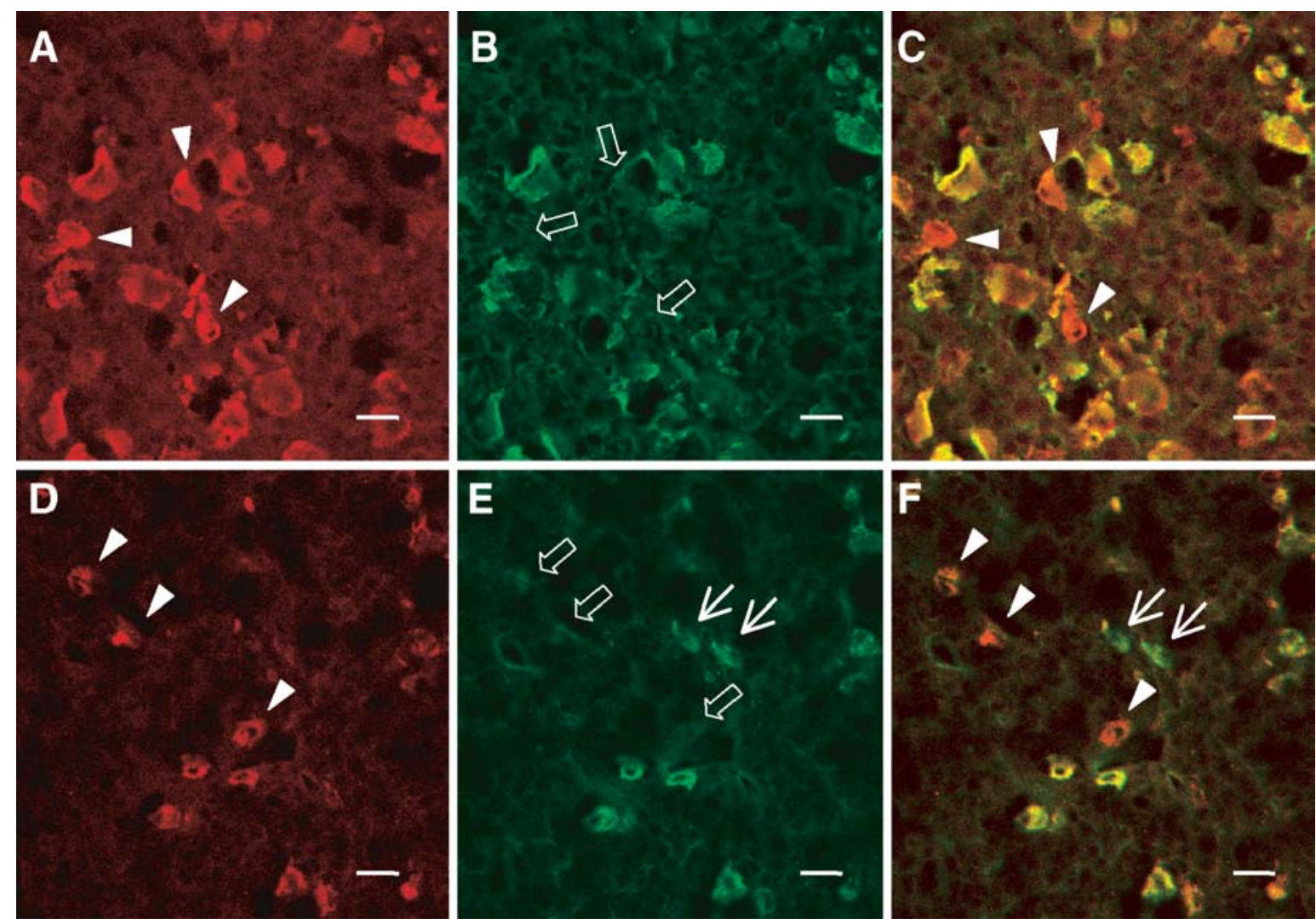

Fig. 4A-F Confocal laser scanning microscope photomicrographs comparing the distribution of WE14, EL35, and LH $\beta$ immunoreactivity in the rat pituitary. Sections through the anterior lobe were labeled with the rabbit antiserum against WE14 (A) or EL35 (D) revealed with Texas red-conjugated donkey anti-rabbit $\gamma$-globulins (DAR/TXR), and with the monoclonal antibody against the LH $\beta$ subunit (B, E) revealed with fluorescein isothiocyanate (FITC)conjugated goat anti-mouse $\gamma$-globulins (GAM/FITC). Combination of the two images acquired in $\mathbf{A}$ and $\mathbf{B}$, and in $\mathbf{D}$ and $\mathbf{E}$ showed the presence of the two CgA-derived peptides in gonadotropes $(\mathbf{C}, \mathbf{F})$. A few cells which were stained by the WE14 or EL35 antibodies (arrowheads) were not LH $\beta$ immunoreactive (open arrows). Reciprocally, a few gonadotropes were not stained by the EL35 antibodies (arrows). Bars $10 \mu \mathrm{m}$

with these tissue extracts were not parallel to that obtained with synthetic human EL35 (Fig. 9B). The apparent concentrations of WE14- and EL35-immunoreactive material were 3 and $513 \mathrm{pg}$ per $\mathrm{mg}$ proteins, respectively, in the adrenal gland and 91 and 564 pg per mg proteins, respectively, in the pituitary gland.

Characterization of WE14 and EL35 immunoreactivity in rat pituitary and adrenal gland extracts

Reversed-phase HPLC analysis combined with RIA detection was conducted to compare the retention time of WE14- and EL35-immunoreactive materials in rat tissue extracts with those of the synthetic peptides. The HPLC profile of synthetic WE14 revealed the existence of two peaks (noted $I$ and $I I$ ) exhibiting retention times of 26 and 33 min (Fig. 10A). As the WE14 molecule possesses a methionine residue which is highly susceptible to oxidation, we suspected that one of the two peaks might correspond to an oxidized form. To test this hypothesis, we incubated the synthetic peptide with hydrogen peroxide under conditions previously shown to oxidize methionine residues (Tranchant-Bunel et al. 1992). This treatment led to an increase of peak II (oxidized form) and a concomitant decrease of peak I (non-oxidized form) (data not shown). The HPLC profile of synthetic EL35 revealed a single immunoreactive peak which

Fig. 5A-F Confocal laser scanning microscope photomicrographs comparing the distribution of WE14, EL35, and ACTH immunoreactivity in the rat pituitary. Sections through the anterior lobe were labeled with the rabbit antiserum against WE14 (A) or EL35 (D) revealed with DAR/TXR, and with the sheep antiserum against ACTH $(\mathbf{B}, \mathbf{E})$ revealed with FITC-conjugated donkey antisheep $\gamma$-globulins (DAS/FITC). Combination of the two images acquired in $\mathbf{A}$ and $\mathbf{B}$, and in $\mathbf{D}$ and $\mathbf{E}$ revealed the absence of the two CgA-derived peptides in corticotropes $(\mathbf{C}, \mathbf{F})$. Bars $10 \mu \mathrm{m}$

Fig. 6A-F Confocal laser scanning microscope photomicrographs comparing the distribution of WE14, EL35, and tyrosine hydroxylase (TH) immunoreactivity in the rat adrenal gland. Sections through the adrenal were labeled with the rabbit antiserum against WE14 (A) or EL35 (D) revealed with DAR-TXR, and with the monoclonal antibody against TH $(\mathbf{B}, \mathbf{E})$ revealed with GAM-FITC. Combination of the two images acquired in $\mathbf{A}$ and $\mathbf{B}$, and in $\mathbf{D}$ and $\mathbf{E}$ revealed the presence of the two $\mathrm{CgA}$-derived peptides in adrenochromaffin $(M)$ but not in adrenocortical $(c x)$ cells (C, F). Bars $10 \mu \mathrm{m}$ 


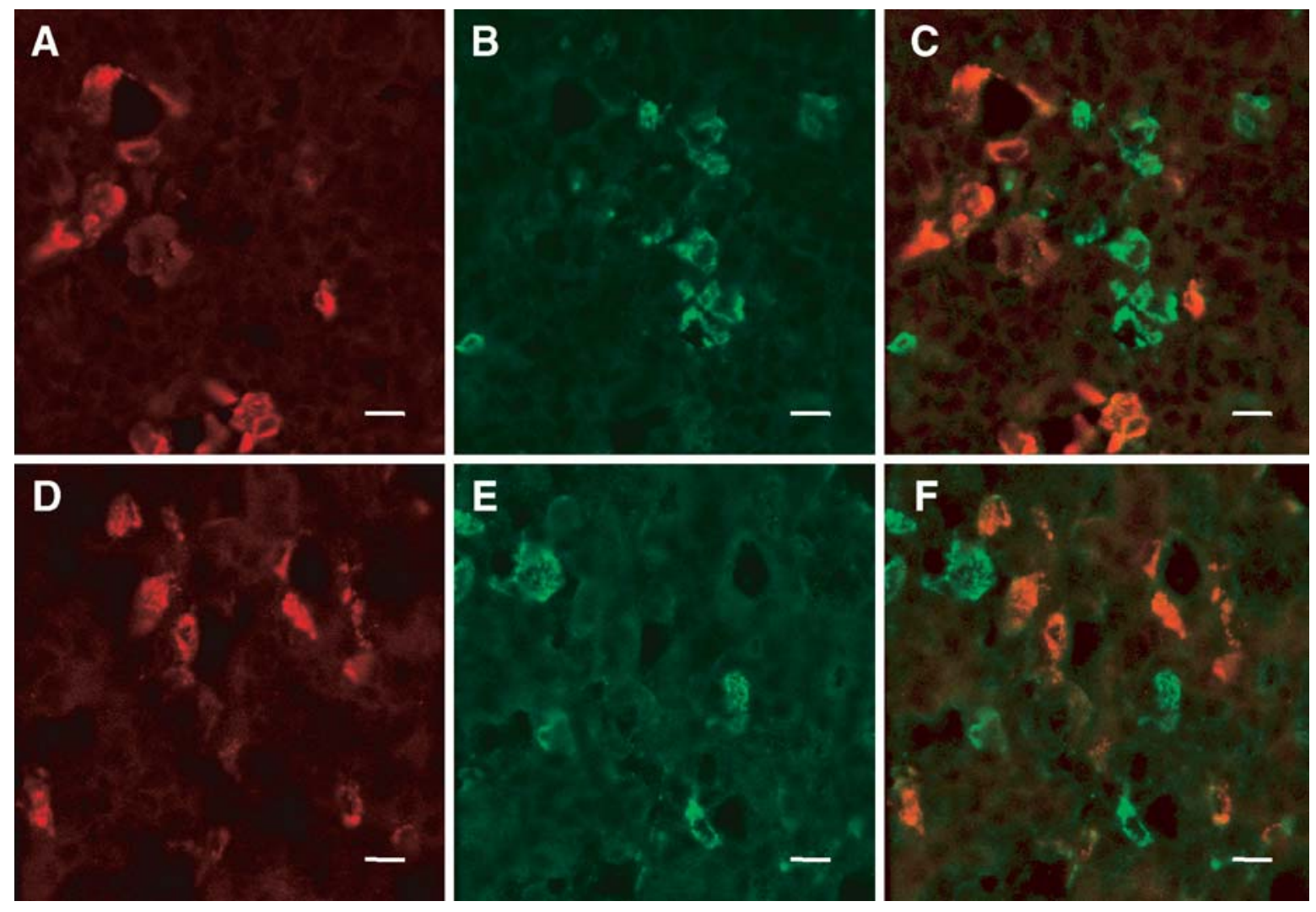

Fig. 5A-F
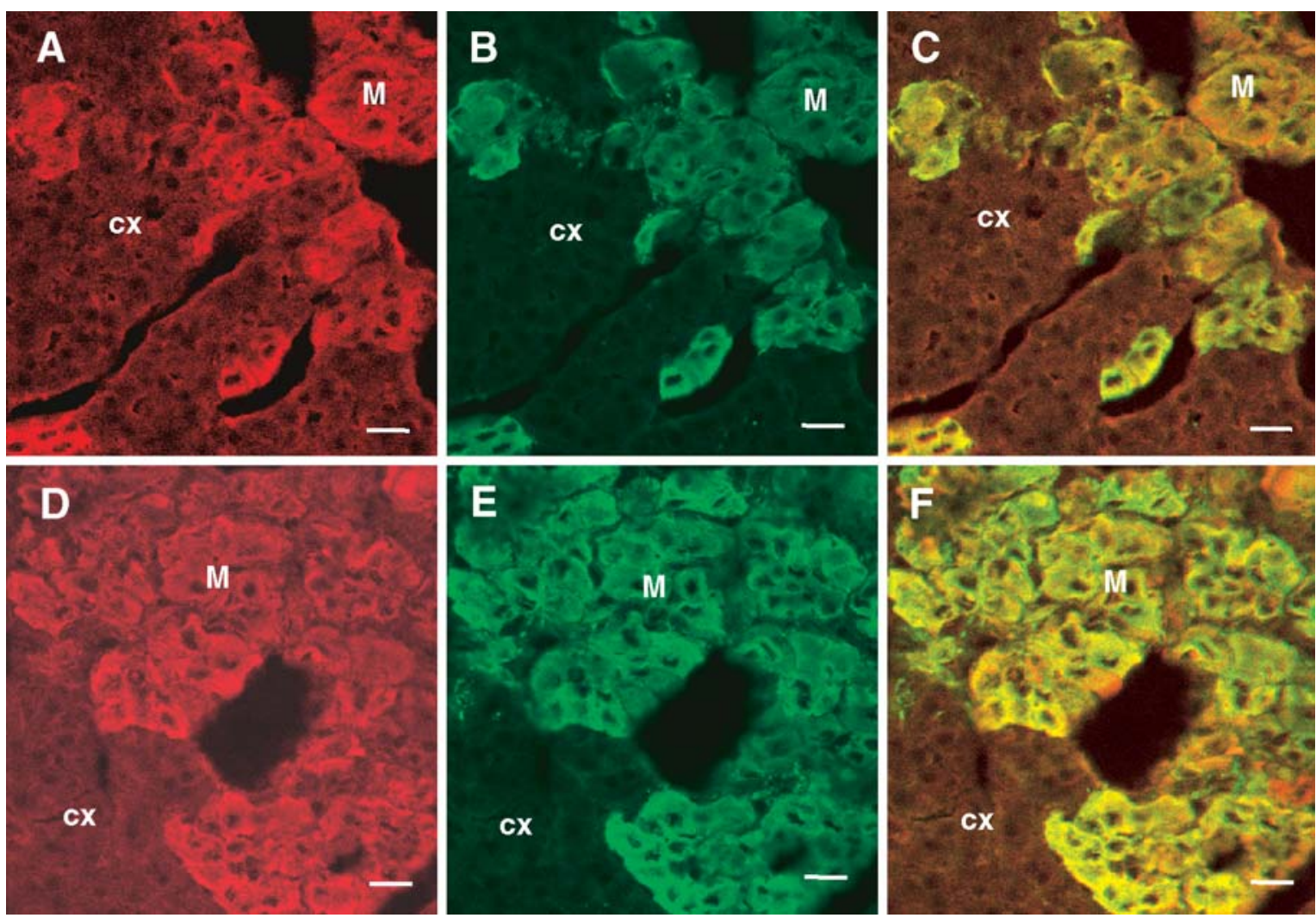

Fig. 6A-F 

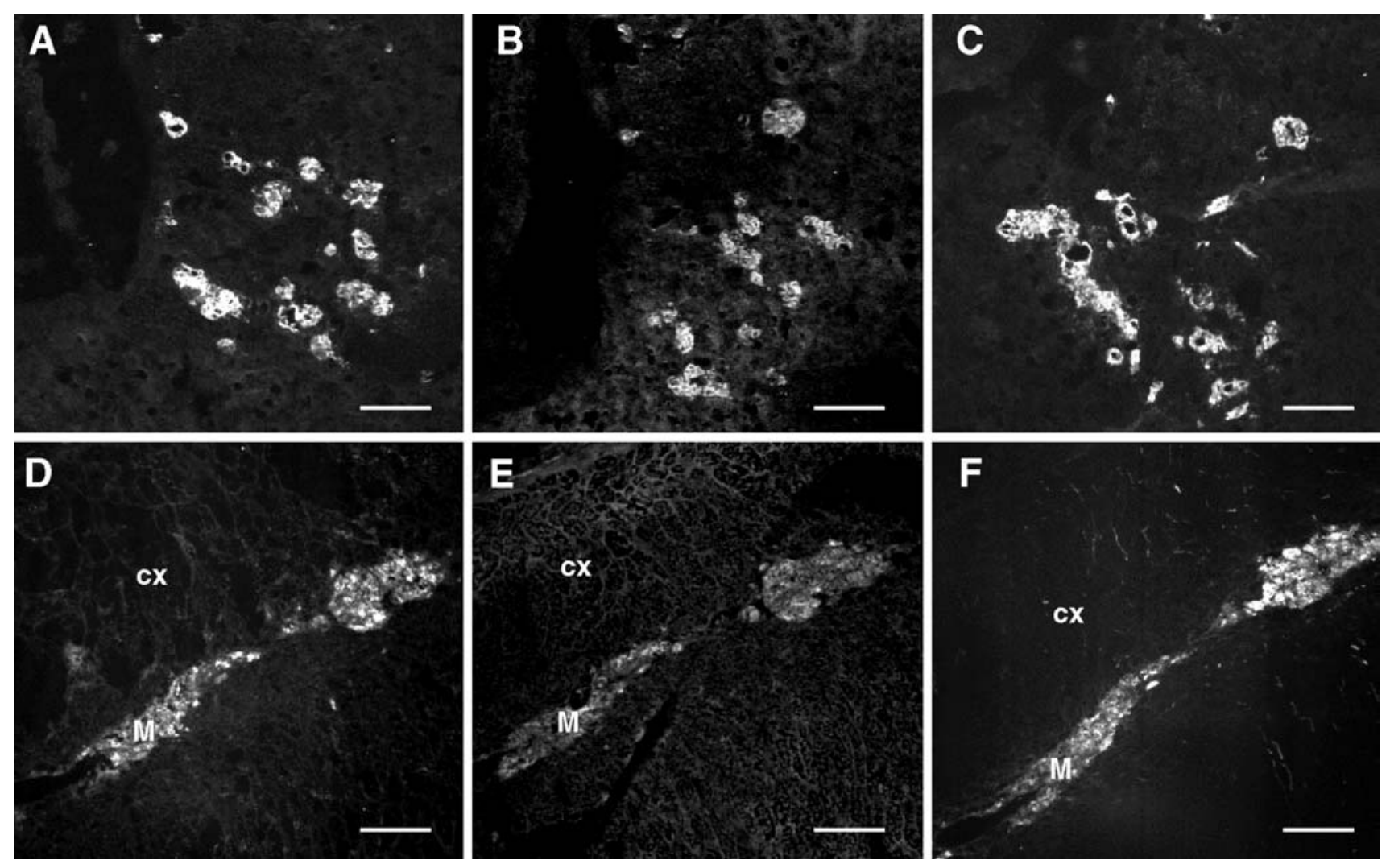

Fig. 7A-F Immunofluorescence labeling of WE14 and EL35 in human adrenal glands. A-C Consecutive sections through a fetal adrenal gland were incubated with antisera against WE14 (A), EL35 (B), and CgA (C). D-F Consecutive sections through an adult adrenal gland were incubated with antibodies against WE14 (D), EL35 (E), and TH (F). All four antibodies specifically stained cells of the medullary zone $(M)$, whereas adrenocortical cells $(c x)$ were devoid of labeling. Bars $25 \mu \mathrm{m}$ in A-C; $200 \mu \mathrm{m}$ in D-F

eluted with a retention time of 50-51 min (Fig. 10B). Analysis of adenohypophyseal extracts showed the occurrence of two major WE14-immunoreactive peaks which co-eluted with those obtained with the synthetic peptide (Fig. 10C). The EL35-immunoreactive material in the anterior lobe was also resolved as two major peaks, one of which (peak I) co-eluted with the synthetic peptide (Fig. 10D). Similar chromatographic profiles were observed with neurointermediate lobe extracts (Fig. 10E, F).

In the adrenal gland extract, two WE14-immunoreactive peaks co-eluting with synthetic standards were detected (Fig. 11A), whereas only one large EL35-immunoreactive peak, which overlapped with peak II resolved from pituitary extracts, was observed (Fig. 11B).

Characterization of WE14 and EL35 immunoreactivity in human adrenal gland extracts

Human fetal adrenal extracts displayed a major WE14immunoreactive peak which exhibited the same retention time as the non-oxidized form of the synthetic peptide (Fig. 12A) and two EL35-immunoreactive peaks, one of which (peak I) co-eluted with the synthetic standard (Fig. 12B). In adult adrenal extracts, a major WE14immunoreactive peak co-eluting with non-oxidized WE14 (Fig. 12C) and a prominent EL35-immunoreactive peak co-eluting with synthetic EL35 (Fig. 12D) were detected. Finally, analysis of a pheochromocytoma extract revealed the occurrence of a high amount of the WE14 peptide (Fig. 12E). In contrast, the EL35 peptide was almost undetectable (peak I) and two other major peaks (peaks II and III) with shorter retention times than EL35 were observed (Fig. 12F).

\section{Discussion}

The cloning of frog CgA (Turquier et al. 1999) has recently revealed the phylogenetic conservation of three peptides located in the $\mathrm{N}$ - and $\mathrm{C}$-terminal regions of the protein, as well as the dibasic sites that can be cleaved by prohormone convertases to generate the free peptides. The fact that evolutionary pressure has acted to preserve the structure of discrete domains of $\mathrm{CgA}$ in species that have diverged some 350 million years ago suggests that the corresponding peptides may represent functional determinants of this protein.

Antibodies were raised against the human amino acid sequences of WE14 and EL35 which both differ by only one amino acid substitution from the rat sequences. Each antibody specifically recognized its cognate peptide and 

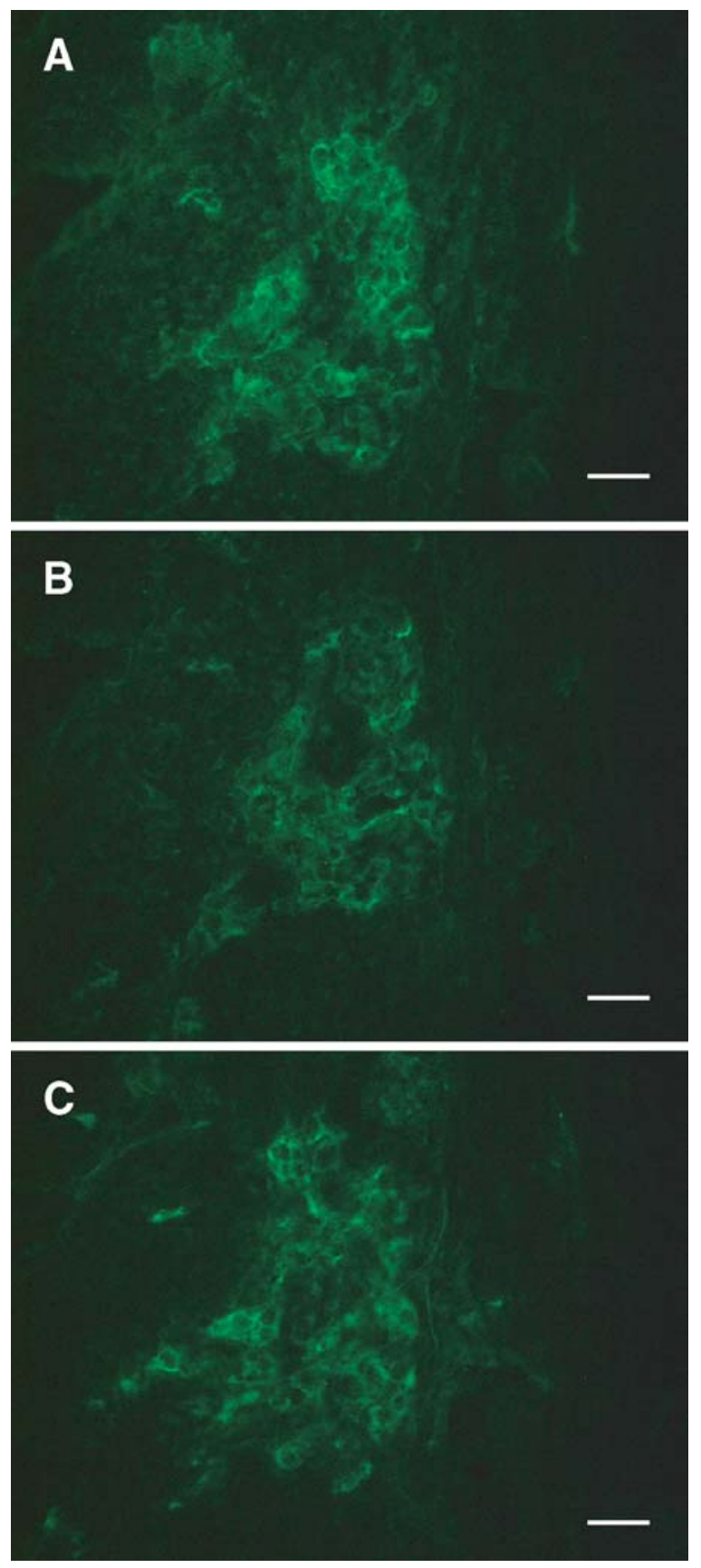

Fig. 8A-C Immunofluorescence labeling of WE14 and EL35 in a human pheochromocytoma. Consecutive sections were incubated with antisera against WE14 (A), EL35 (B), and CgA (C). All three antisera specifically labeled tumoral chromaffin cells. Bars $60 \mu \mathrm{m}$

did not exhibit any cross-reactivity with unrelated peptides as determined by RIA. Western blot analysis of rat pituitary and adrenal gland extracts showed that WE14 and EL35 antibodies also recognized to some extent $\mathrm{CgA}$ and derived intermediate processing products. Interestingly, different immunoreactive products were resolved in the pituitary and adrenal extracts, indicating that the processing of $\mathrm{CgA}$ in endocrine glands is tissuespecific. This observation is in line with previous studies
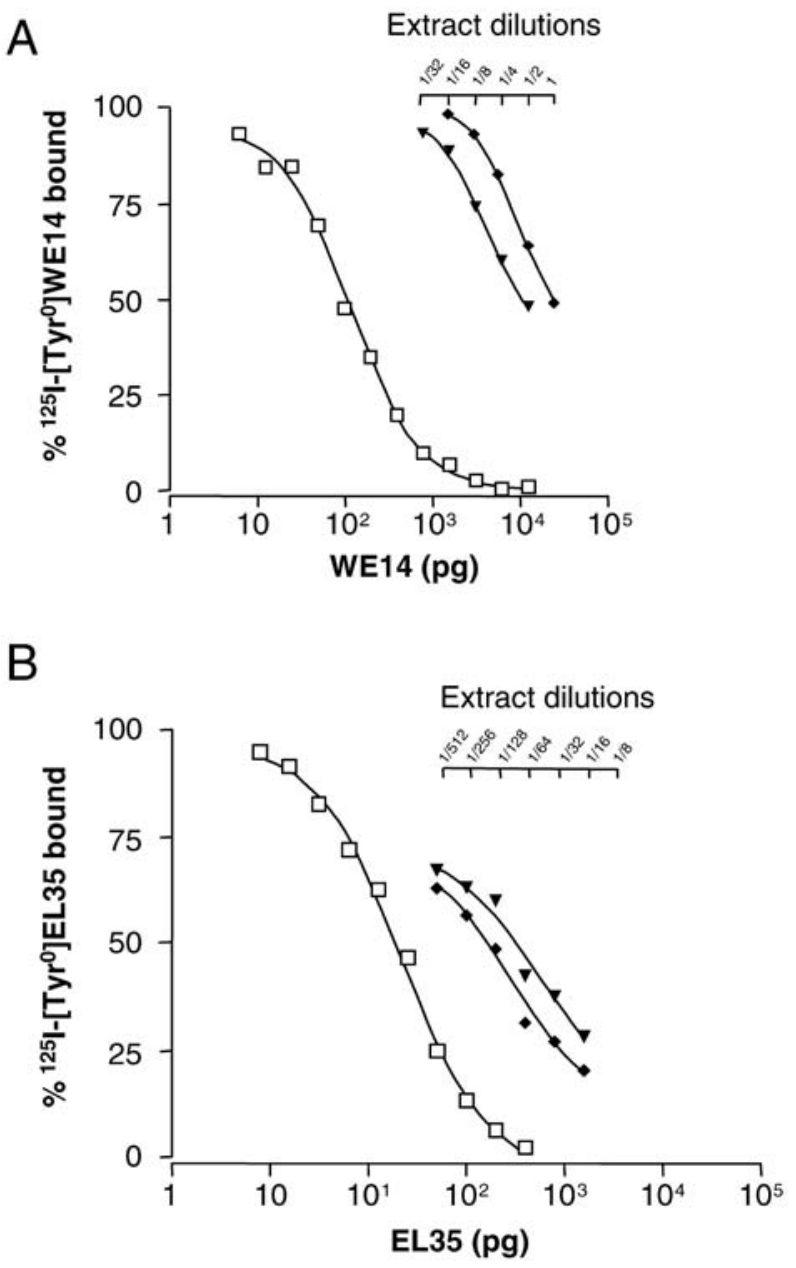

Fig. 9 Semilogarithmic plots comparing competitive inhibition of antibody-bound ${ }^{125}$ I-labeled $\left[\mathrm{Tyr}^{0}\right] \mathrm{WE} 14$ (A) or ${ }^{125}$ I-labeled $\left[\mathrm{Tyr}^{0}\right]$ EL35 (B) by synthetic WE14 or synthetic EL35, respectively, and by serial dilutions of rat pituitary (solid triangles) and adrenal gland (solid diamonds) extracts. Dilution 1 corresponds to $100 \mu \mathrm{l}$ tissue extract which was prepared from ten glands in $420 \mu \mathrm{l}$ buffer

on $\mathrm{CgA}$ proteolytic cleavage in the digestive tract, the anterior pituitary, the thyroid (Curry et al. 1991; Norlén et al. 2001), and in different tumor cell lines (Deftos et al. 1990; Portel-Gomes et al. 2001). The differential processing of CgA may be ascribed to the effect of a cellspecific repertoire of enzymes or to the same enzymes whose activity varies depending on the cell type. In addition, the cleavage efficacy at the various dibasic sites may differ in a given cell type, leading to different amounts of mature peptides. As a matter of fact, RIA quantification showed that EL35 is produced at a much higher rate than WE14 in both the adrenal and the pituitary. This result is consistent with the observation that the cleavage of $\mathrm{CgA}$ occurs preferentially at the $\mathrm{N}$ - and C-terminal extremities of the protein (Wohlfarter et al. 1988; Deftos et al. 1990; Curry et al. 1991; MetzBoutigue et al. 1993). 
Fig. 10A-F Reversed-phase high-performance liquid chromatography (RP-HPLC) analysis of WE14- and EL35-like immunoreactivity (li) in the rat pituitary. A, B Elution profiles of synthetic WE14 (A) and EL35 (B). C, D Extracts of 20 anterior lobes were prepurified on Sep-Pak cartridges and chromatographed onto a Vydac $\mathrm{C}_{18}$ column. Fractions (1 ml each) were collected, dried, and radioimmunoassayed for WE14 (C) or EL35 (D). E, F Extracts of 36 neurointermediate lobes were analyzed as described above and radioimmunoassayed for WE14 (E) or EL35 (F). The bars above the peaks indicate the elution position of synthetic non-oxidized WE14 (peak I), oxidized WE14 (peak II), and EL35 (peak I) as determined in $\mathbf{A}$ and $\mathbf{B}$, respectively
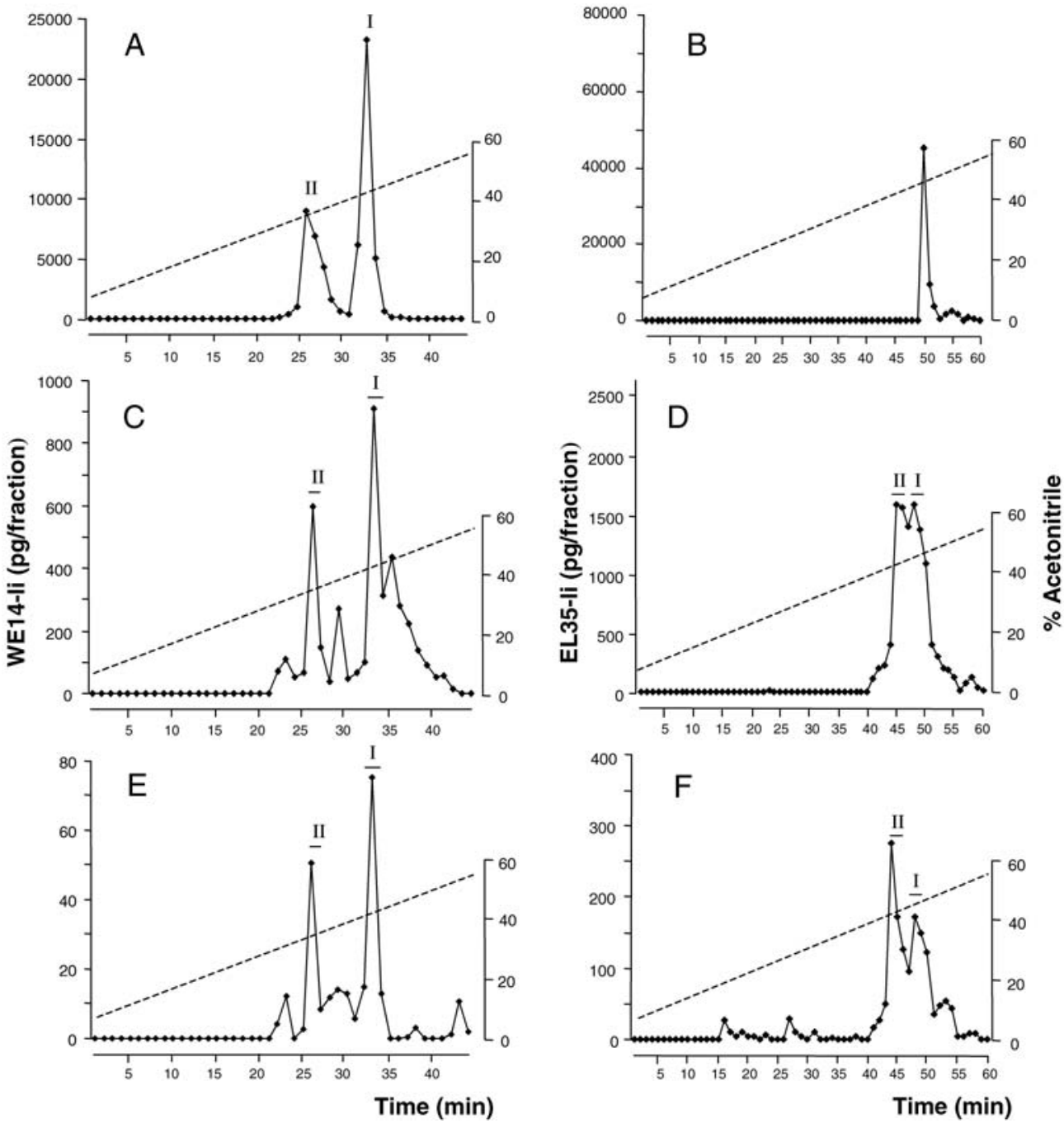

The HPLC characterization of WE14 immunoreactivity revealed that this peptide is formed in the anterior and neurointermediate lobes of the rat pituitary as well as in the adrenal gland. Recently, WE14 has been also characterized in the gastro-entero-pancreatic system (Gleeson et al. 1996; Norlén et al. 1997, 2001) and in human pituitary adenoma (Heaney et al. 2000). Along with the present results showing that WE14 is also generated in both the adenohypophysis and the pars intermedia of the normal pituitary, and in the adrenal gland, these data indicate that WE14 could be formed in a variety of endocrine and neuroendocrine cells.

Two EL35 molecular forms were detected in the anterior and neurointermediate lobes of the rat pituitary, one of which co-eluted with synthetic human EL35. In the rat adrenal gland, only the form with a shorter retention time than EL35 was observed. These findings are in line with the RIA analysis which showed that the displacement curves obtained with crude pituitary and adrenal extracts were not parallel to that produced by the synthetic peptide, indicative of the existence of several EL35-immunoreactive forms. The identity of the other immunoreactive material could not be determined from our data but it should be mentioned that EL35 possesses an internal pair of basic residues which could be cleaved in a cell-specific manner to give rise to a shorter peptide. Alternatively, this additional form may represent a larger $\mathrm{CgA}$-derived fragment encompassing the EL35 sequence.

Co-localization studies in the rat adenohypophysis using confocal microscopy showed that WE14 and EL35 are present in gonadotropes of the pituitary, although some gonadotropes do not produce these peptides. Previous studies have shown that $\mathrm{CgA}$ expression is strongly regulated by steroid hormones in gonadotropes (FischerColbrie et al. 1989; Anouar et al. 1991; Watanabe et al. 1998). It would be interesting to determine the influence of these hormones on the production of $\mathrm{CgA}$-derived peptides such as WE14 and EL35 from these cells. These studies may help to understand the role of WE14 and EL35 in gonadotrope function. However, WE14 and EL35 are not present exclusively in gonadotropes since certain WE14- and EL35-positive cells were negative for LH $\beta$ staining. Corticotropes did not exhibit any WE14or EL35-li in accordance with the report of Fischer- 

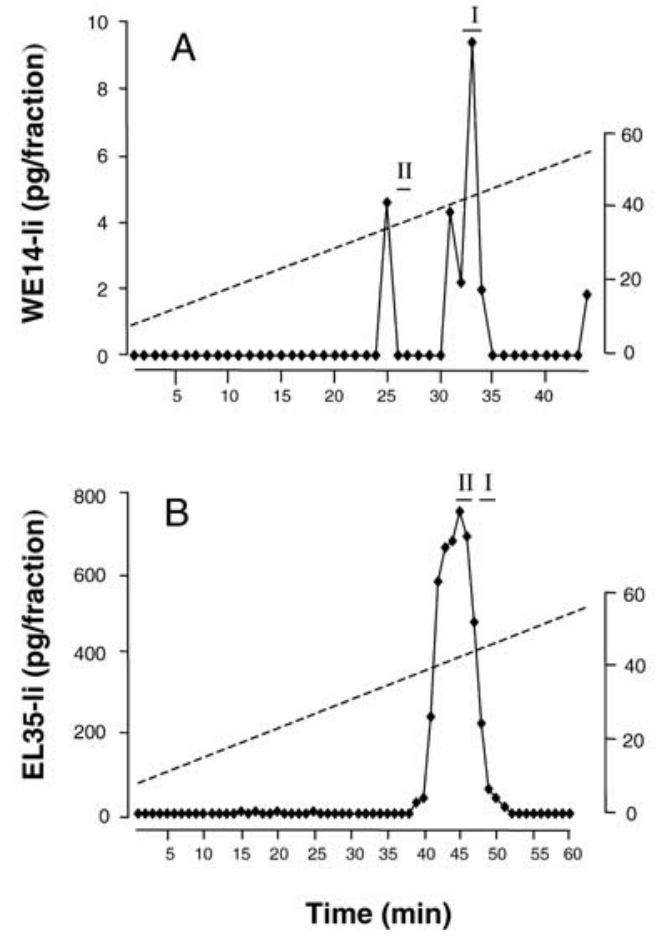

Fig. 11A, B Reversed-phase HPLC analysis of WE14- and EL35like immunoreactivity (li) in the rat adrenal gland. Extracts of 40 whole rat adrenals were prepurified on Sep-Pak cartridges, analyzed by HPLC, and radioimmunoassayed for WE14 (A) or EL35 (B). The bars above the peaks indicate the elution position of synthetic non-oxidized WE14 (peak I), oxidized WE14 (peak II), and EL35 (peak I). See legend to Fig. 10 for other designations

Colbrie et al. (1989) showing that $\mathrm{CgA}$ is not expressed in the rat corticotropes. The other pituitary cells that were immunostained for WE14 and EL35 could be thyrotropes, which have been shown to contain $\mathrm{CgA}$ immunoreactivity (Cohn et al. 1984), lactotropes and/or somatotropes which are also known to contain several granins (Winkler and Fischer-Colbrie 1992; Rosa and Gerdes 1994). In addition to adenohypophyseal cells, we found that melanotropes of the intermediate lobe of the pituitary are also able to produce WE14 and EL35, thus revealing the expression of $\mathrm{CgA}$ and processed peptides in rat melanotropes. The cleavage of the dibasic sites at the boundaries of WE14 and EL35 in the pituitary is probably performed by the subtilisin-kexin-like prohormone convertases PC1 and PC2 whose expression in pituitary cells is well documented (Marcinkiewicz et al. 1993; Eskeland et al. 1996). In support of this hypothesis, it has been shown by overexpression or by antisense reduction of PC1 and PC2 that these enzymes are involved in the processing of $\mathrm{CgA}$ in tumoral corticotrope AtT-20 cells (Eskeland et al. 1996).

We also demonstrated the occurrence of WE14 and EL35 in the rat and human adrenal glands. The processing mechanism of $\mathrm{CgA}$ in the adrenal gland is not fully understood. Chromogranin A is less processed in the adrenal medulla than in other tissues such as the intestine, peripheral nerves, or pancreas (Winkler and FischerColbrie 1992; Iacangelo and Eiden 1995). However, it has been shown that depletion of catecholamine stores from adrenochromaffin cells by reserpine treatment is accompanied by an increase of the rate of $\mathrm{CgA}$ processing and that high concentrations of catecholamines inhibit PC1 activity in vitro (Wolkersdorfer et al. 1996). These observations suggest that, under certain circumstances, $\mathrm{CgA}$ could be efficiently cleaved in the adrenal, probably by prohormone convertases, to generate fully processed peptides. Immunohistochemical labeling showed that WE14- and EL35-li are present in all THpositive, i.e., adrenergic and noradrenergic, cells of the rat adrenal gland. Staining of human adrenal slices with WE14 or EL35 antisera revealed intense labeling of adrenomedullary cells in the adult gland and nests of chromaffin progenitor cells in the developing adrenal. Together with the HPLC data, these observations indicate that production of WE14 and EL35 occurs early during embryogenesis of the adrenal gland and is maintained in adulthood. Consistently, ontogenetic studies in the rat neuroendocrine system have shown that the immunoreactivity of $\mathrm{CgA}$ and derived peptides could be detected early during fetal development of several endocrine and neuroendocrine cells (Barkatullah et al. 1997). However, our studies reveal that, while WE14 occurs as a single molecular form in both rat and human adrenal gland extracts, the novel peptide EL35 exhibits distinct elution profiles depending on the tissues, indicating the existence of closely related but different forms of EL35 in these tissues.

At present, the physiological significance of the occurrence of WE14 and EL35 in the pituitary and adrenal is not known. It has recently been shown that depletion of $\mathrm{CgA}$ provokes the disappearance of secretory granules in neuroendocrine cells, indicating that $\mathrm{CgA}$ plays a fundamental role in the biogenesis of dense-core vesicles (Kim et al. 2001). The fact that evolutionary pressure has acted to conserve peptides such as WE14 and EL35 which are selectively produced in rat and human endocrine cells, even at early stages of development as shown in the present study, suggests that these peptides may play specific functions in the endocrine and neuroendocrine systems. The WE14 and EL35 sequences could represent structural determinants for an intravesicular role of CgA. Alternatively, WE14 and EL35 may play a role as autocrine, paracrine, or endocrine regulatory peptides.

Chromogranin A has proven to be a useful histological marker for neuroendocrine tumor identification (Deftos 1991; Rosa and Gerdes 1994). Chromogranin A has been originally purified from catecholamine storage vesicles of pheochromocytoma (O'Connor et al. 1984) and circulating levels of $\mathrm{CgA}$ are elevated in patients with this type of tumor (O'Connor and Bernstein 1984; Eriksson et al. 1989; Deftos 1991). Our immunohistochemical data show the occurrence of clusters of WE14- and EL35-immunoreactive cells in a pheochromocytoma. As had been previously reported by Conlon et al. (1992), HPLC analysis confirmed the presence of WE14 in pheochromocyto- 
Fig. 12A-F Reversed-phase HPLC analysis of WE14- and EL35-like immunoreactivity (li) in the human adrenal gland and in human pheochromocytoma. Tissue extracts from fetal adrenals (two glands from 20week-old fetuses; A, B), adult adrenal (1 g tissue; C, D), and pheochromocytoma (1 g tissue; $\mathbf{E}, \mathbf{F})$ were prepurified on SepPak cartridges, analyzed by HPLC, and radioimmunoassayed for WE14 (A, C, E) or $\operatorname{EL} 35$ (B, D, F). The bars above the peaks indicate the elution position of synthetic non-oxidized WE14 (peak I), oxidized WE14 (peak II), and EL35 (peak I). See legend to Fig. 10 for other designations
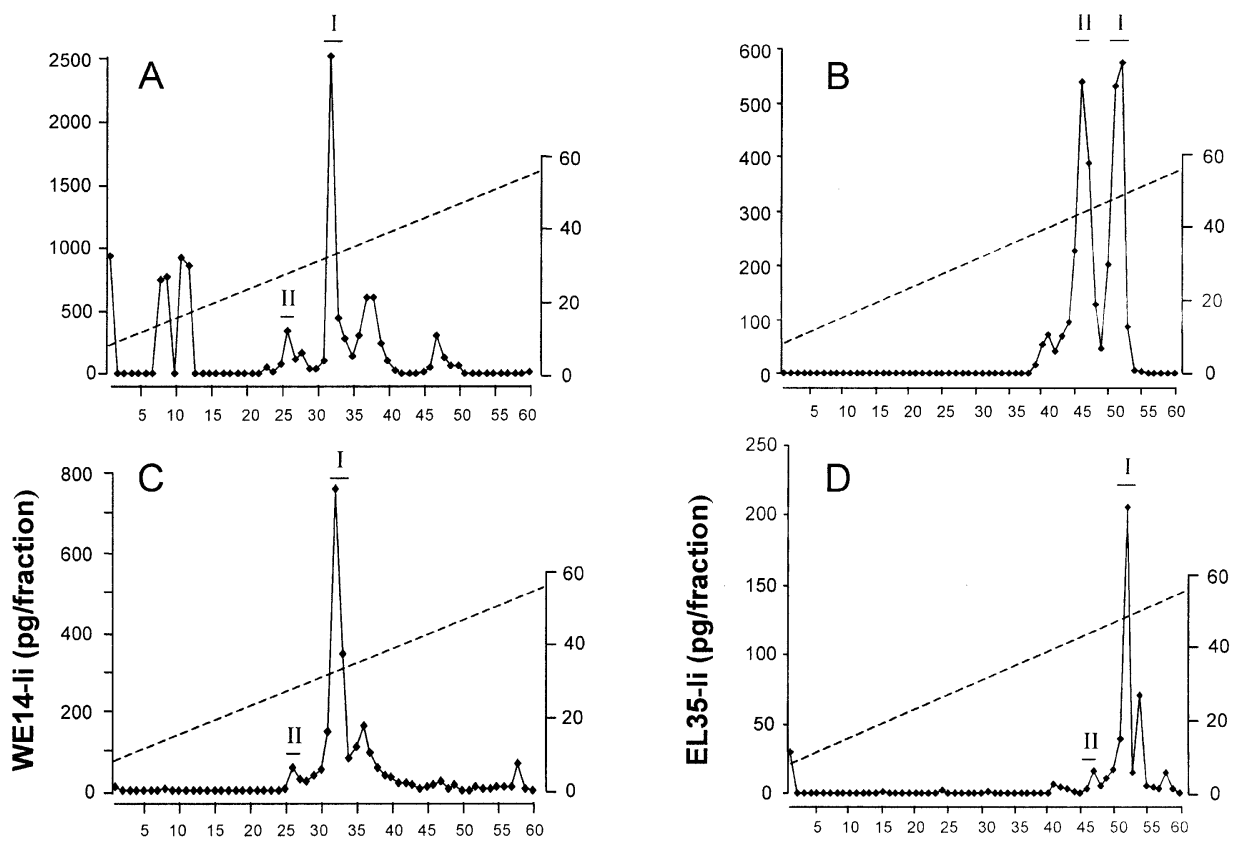

مْ

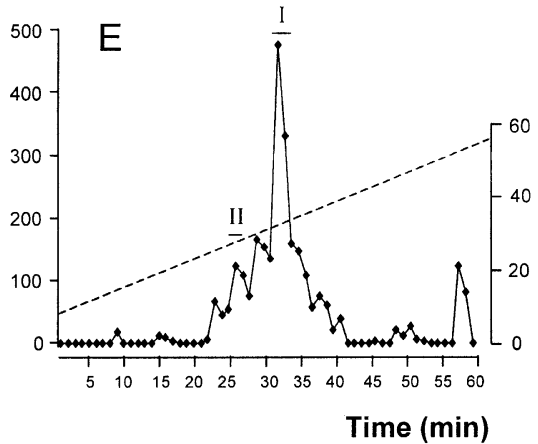

ma tissue. In contrast, only minute amounts of authentic EL35 could be detected and other EL35-immunoreactive forms were observed. Since the EL35 peptide is present in the adult human adrenal gland, it can be hypothesized that the processing of this peptide is altered in tumorous tissue. It has been recently shown that the immunoreactivity of the N-terminal portion of $\mathrm{CgA}$ (VS I) can discriminate metastatic deposits of ileum or lung carcinoids (Cunningham et al. 1999). Similarly, the concentration of the SgII-derived peptide SN is markedly increased in endocrine tumors such as gut carcinoids, endocrine pancreatic tumors, lung carcinomas, and pheochromocytomas, but not in neuroblastomas, insulinomas, pituitary adenomas, and non-endocrine tumors (Ischia et al. 2000). Collectively, these observations suggest that assessment of granin-derived peptides, such as VS I, SN, or EL35, in tissues and/or in the plasma of patients may represent a valuable approach for the diagnosis and prognosis of neuroendocrine tumors.

Acknowledgements The authors are very grateful to C. Rousselle and $\mathrm{H}$. Lemonnier for their skillful technical assistance, Dr. V. Contesse for supplying human adrenal tissues, and Drs. J.F. Roser (Davis, Calif., USA) and J. Cote (Laval University, Quebec, Canada) for providing the $\mathrm{LH} \beta$ and ACTH antisera, respectively.

\section{References}

Aardal S, Helle KB, Elsayed S, Reed RK, Serck-Hanssen G (1993) Vasostatins, comprising the N-terminal domain of chromogranin A, suppress tension in isolated human blood vessel segments. J Neuroendocrinol 5:405-412

Aït-Ali D, Turquier V, Alexandre D, Grumolato L, Jégou S, Vaudry H, Anouar Y (2002) Molecular characterization of frog chromogranin B reveals conservation of selective sequences encoding potential novel regulatory peptides. FEBS Lett 511:127-132

Anouar Y, Benie T, De Monti M, Counis R, Duval J (1991) Estradiol negatively regulates secretogranin II and chromogranin A messenger ribonucleic acid levels in the female rat pituitary but not in the adrenal. Endocrinology 129:2393-2399

Anouar Y, Jégou S, Alexandre D, Lihrmann I, Conlon JM, Vaudry H (1996) Molecular cloning of frog secretogranin II reveals the occurrence of several highly conserved potential regulatory peptides. FEBS Lett 394:295-299

Barkatullah SC, Curry WJ, Johnston CF, Hutton JC, Buchanan KD (1997) Ontogenetic expression of chromogranin A and its derived peptides, WE14 and pancreastatin, in the rat neuroendocrine system. Histochem Cell Biol 107:251-257

Benedum UM, Lamouroux A, Konecki DS, Rosa P, Hille A, Baeuerle PA, Franck R, Lottspeich F, Mallet J, Huttner WB (1987) The primary structure of human secretogranin I (chromogranin B): comparison with chromogranin A reveals homologous terminal domains and a large intervening variable region. EMBO J 6:1203-1211 
Blazquez M, Bosma PT, Chang JP, Docherty K, Trudeau VL (1998) $\gamma$-Aminobutyric acid up-regulates the expression of a novel secretogranin-II messenger ribonucleic acid in the goldfish pituitary. Endocrinology 139:4870-4880

Cohn DV, Elting JJ, Frick M, Elde R (1984) Selective localization of the parathyroid secretory protein-I/adrenal medulla chromogranin A protein family in a wide variety of endocrine cells of the rat. Endocrinology 114:1963-1974

Conlon JM, Hamberger B, Grimelius L (1992) Isolation of peptides arising from the specific posttranslational processing of chromogranin A and chromogranin B from human pheochromocytoma tissue. Peptides 13:639-644

Cunningham RT, Pogue KM, Curry WJ, Johnston CF, Sloan JM, Buchanan KD (1999) Immunostaining for vasostatin I distinguishes between ileal and lung carcinoids. J Pathol 187:321325

Curry WJ, Johnston CF, Hutton JC, Arden SD, Rutherford NG, Shaw C, Buchanan KD (1991) The tissue distribution of rat chromogranin A-derived peptides: evidence for differential tissue processing from sequence specific antisera. Histochemistry 96:513-518

Curry WJ, Shaw C, Johnston CF, Thim L, Buchanan KD (1992) Isolation and primary structure of a novel chromogranin A-derived peptide, WE-14, from a human midgut carcinoid tumour. FEBS Lett 301:319-321

Deftos LJ (1991) Chromogranin A: its role in endocrine function and as an endocrine and neuroendocrine tumor marker. Endocr Rev 12:181-187

Deftos LJ, Gazdar AF, Hogue-Angeletti R, Mullen PS, Burton DW (1990) Distinct patterns of chromogranin A-related species can be demonstrated in endocrine cells. Bone Mineral 9:169-178

Eriksson B, Arnberg H, Oberg K, Hellman U, Lundqvist G, Wernstedt C, Wilander E (1989) Chromogranins: new sensitive markers for neuroendocrine tumors. Acta Oncol 28:325329

Eskeland NL, Zhou A, Dinh TQ, Wu H, Parmer RJ, Mains RE, O'Connor DT (1996) Chromogranin A processing and secretion. Specific role of endogenous and exogenous prohormone convertases in the regulated secretory pathway. J Clin Invest 98:148-156

Fischer-Colbrie R, Wohlfarter T, Schmid KW, Grino M, Winkler $H$ (1989) Dexamethasone induces an increased biosynthesis of chromogranin A in rat pituitary gland. J Endocrinol 121:487494

Gerdes HH, Rosa P, Phillips E, Baeuerle PA, Franck R, Argos P, Huttner WB (1989) The primary structure of human secretogranin II, a widespread tyrosine-sulfated secretory granule protein that exhibits low $\mathrm{pH}$ - and calcium-induced aggregation. J Biol Chem 264:12009-12015

Gleeson CM, Curry WJ, Johnston CF, Buchanan KD (1996) Occurrence of WE-14 and chromogranin A-derived peptides in tissues of the human and bovine gastro-entero-pancreatic system and in human neuroendocrine neoplasia. J Endocrinol 151:409-420

Heaney AP, Curry WJ, Pogue KM, Armstrong VL, Mirakhur M, Sheridan B, Johnston CF, Buchanan KD, Atkinson AB (2000) Immunohistochemical evaluation of the post-translational processing of chromogranin A in human pituitary adenomas. Pituitary 3:67-75

Helle KB (2000) The chromogranins. Historical perspectives. Adv Exp Med Biol 482:3-20

Holthuis JC, Martens GJ (1996) The neuroendocrine proteins secretogranin II and III are regionally conserved and coordinately expressed with proopiomelanocortin in Xenopus intermediate pituitary. J Neurochem 66:2248-2256

Iacangelo AL, Eiden LE (1995) Chromogranin A: current status as a precursor for bioactive peptides and a granulogenic/sorting factor in the regulated secretory pathway. Regul Pept 58:6588

Iacangelo A, Affolter HU, Eiden LE, Herbert E, Grimes M (1986) Bovine chromogranin A sequence and distribution of its messenger RNA in endocrine tissues. Nature 323:82-86
Iacangelo AL, Fischer-Colbrie R, Koller KJ, Brownstein MJ, Eiden LE (1988) The sequence of porcine chromogranin A messenger RNA demonstrates chromogranin A can serve as the precursor for the biologically active hormone, pancreastatin. Endocrinology 122:2339-2341

Ischia R, Gasser RW, Fischer-Colbrie R, Eder U, Pagani A, Cubeddu LX, Lovisetti-Scamihorn P, Finkenstedt G, Laslop A, Winkler H (2000) Levels and molecular properties of secretoneurin-immunoreactivity in the serum and urine of control and neuroendocrine tumor patients. J Clin Endocrinol Metab $85: 355-360$

Jégou S, Tonon MC, Leroux P, Delarue C, Leboulenger F, Pelletier G, Cote J, Ling N, Vaudry H (1983) Immunological characterization of endorphins, adrenocorticotropin, and melanotropins in frog hypothalamus. Gen Comp Endocrinol $51: 246-254$

Kim T, Tao-Cheng JH, Eiden LE, Peng-Loh Y (2001) Chromogranin A, an "on/off" switch controlling dense-core secretory granule biogenesis. Cell 106:499-509

Leitner B, Schneitler C, Klocker H, Volknandt W, Zimmermann H, Winkler H, Fischer-Colbrie R (1998) Formation and sequence analysis of secretoneurin, a neuropeptide derived from secretogranin II, in mammalian, bird, reptile, amphibian and fish brains. Neurosci Lett 248:105-108

Leprince J, Gandolfo P, Thoumas JL, Patte C, Fauchere JL, Vaudry H, Tonon MC (1998) Structure-activity relationships of a series of analogues of the octadecaneuropeptide ODN on calcium mobilization in rat astrocytes. J Med Chem 41:44334438

Lugardon K, Raffner R, Goumon Y, Corti A, Delmas A, Bulet P, Aunis D, Metz-Boutigue MH (2000) Antibacterial and antifungal activities of vasostatin-1, the N-terminal fragment of chromogranin A. J Biol Chem 275:10745-10753

Mahata SK, Mahata M, Wakade AR, O'Connor DT (2000) Primary structure and function of the catecholamine release inhibitory peptide catestatin [chromogranin A(344-364)]: identification of amino acid residues crucial for activity. Mol Endocrinol 14:1525-1535

Marcinkiewicz M, Day R, Seidah NG, Chrétien M (1993) Ontogeny of the prohormone convertases PC1 and PC2 in the mouse hypophysis and their colocalization with corticotropin and $\alpha$-melanotropin. Proc Natl Acad Sci U S A 90:4922-4926

Matteri RL, Roser JF, Baldwin DM, Lipovetsky V, Papkoff H (1987) Characterization of a monoclonal antibody which detects luteinizing hormone from diverse mammalian species. Domest Anim Endocrinol 4:157-165

Metz-Boutigue MH, Garcia-Sablone P, Hogue-Angeletti R, Aunis D (1993) Intracellular and extracellular processing of chromogranin A. Determination of cleavage sites. Eur J Biochem 217:247-257

Norlén P, Curry WJ, Chen D, Zhao CM, Johnston CF, Hakanson R (1997) Expression of the chromogranin A-derived peptides pancreastatin and WE14 in rat stomach ECL cells. Regul Pept 70:121-133

Norlén P, Curry WJ, Bjorkqvist M, Maule A, Cunningham RT, Hogg RB, Harriott P, Johnston CF, Hutton JC, Hakanson R (2001) Cell-specific processing of chromogranin A in endocrine cells of the rat stomach. J Histochem Cytochem 49:9-18

O'Connor DT, Bernstein KN (1984) Radioimmunoassay of chromogranin A in plasma as a measure of exocytotic sympathoadrenal activity in normal subjects and patients with pheochromocytoma. N Engl J Med 311:764-770

O'Connor DT, Frigon RP, Sokoloff RL (1984) Human chromogranin A. Purification and characterization from catecholamine storage vesicles of human pheochromocytoma. Hypertension $6: 2-12$

Portel-Gomes GM, Grimelius L, Johansson H, Wilander E, S tridsberg M (2001) Chromogranin A in human neuroendocrine tumors: an immunohistochemical study with region-specific antibodies. Am J Surg Pathol 25:1261-1267

Rosa P, Gerdes HH (1994) The granin protein family: markers for neuroendocrine cells and tools for the diagnosis of neuroendocrine tumors. J Endocrinol Invest 17:207-225 
Stridsberg M, Angeletti RH, Helle KB (2000) Characterisation of $\mathrm{N}$-terminal chromogranin A and chromogranin B in mammals by region-specific radioimmunoassays and chromatographic separation methods. J Endocrinol 165:703-714

Tatemoto K, Efendic S, Mutt V, Makk G, Feistner GJ, Barchas JD (1986) Pancreastatin, a novel pancreatic peptide that inhibits insulin secretion. Nature 324:476-478

Tranchant-Bunel D, Conlon JM, Chartrel N, Tonon MC, Vaudry H (1992) Isolation and structural characterization of peptides related to $\alpha$ - and $\gamma$-melanocyte-stimulating hormone (MSH) from the frog brain. Mol Brain Res 15:1-7

Turquier V, Vaudry H, Jégou S, Anouar Y (1999) Frog chromogranin A messenger ribonucleic acid encodes three highly conserved peptides. Coordinate regulation of proopiomelanocortin and chromogranin A gene expression in the pars intermedia of the pituitary during background color adaptation. Endocrinology 140:4104-4112

Turquier V, Vaudry H, Montero M, Yon L, Anouar Y (2000) Characterization of chromogranins in the frog Rana ridibunda. Structure, expression, and functional implications. Adv Exp Med Biol 482:125-136
Vaudry H, Conlon JM (1991) Identification of a peptide arising from the specific post-translation processing of secretogranin II. FEBS Lett 284:31-33

Watanabe T, Banno T, Jeziorowski T, Ohsawa Y, Waguri S, Grube D, Uchiyama Y (1998) Effects of sex steroids on secretory granule formation in gonadotropes of castrated male rats with respect to granin expression. Endocrinology 139:27652773

Wiedermann CJ (2000) Secretoneurin: a functional neuropeptide in health and disease. Peptides 21:1289-1298

Winkler H, Fischer-Colbrie R (1992) The chromogranins A and B: the first 25 years and future perspectives. Neuroscience 49:497-528

Wohlfarter T, Fischer-Colbrie R, Hogue-Angeletti R, Eiden LE, Winkler H (1988) Processing of chromogranin A within chromaffin granules starts at $\mathrm{C}$ - and $\mathrm{N}$-terminal cleavage sites. FEBS Lett 231:67-70

Wolkersdorfer M, Laslop A, Lazure C, Fischer-Colbrie R, Winkler $\mathrm{H}$ (1996) Processing of chromogranins in chromaffin cell culture: effects of reserpine and $\alpha$-methyl- $p$-tyrosine. Biochem $\mathbf{J}$ 316:953-958 